\title{
THE BLANKON: UNIQUE BEVERAGE WITH DISTINCTIVE AROMA FROM KAWISTA
}

\author{
Khinsa Naura Nisrinathira*)1, Lokita Rizky Megawati"), and M. Syamsul Ma'arif*) \\ *) School of Business, IPB University \\ Jl. Pajajaran, Bogor 16151
}

\begin{abstract}
Kawista is a fruit that belongs to oranges, it has round shape with thick and hard skin and special aroma. The purpose of this research is to identify customer needs for non-coffee beverage and produce The Blankon. The method used was customer development that is focused on customer discovery by using canvas model. The study conducted in coffee shops in Bogor City from February to March 2020. The results showed that The Blankon answered the customers' wants. The sweet levels classified as adequate (not too sweet) and not leaving traces of sweetness in the mouth. The Blankon has distinctive aroma, and refreshing as drinks. Based on the result, about $92 \%$ of respondents were potential to choose The Blankon as their beverages.
\end{abstract}

Keywords: build the product, business model canvas, customer discovery, kawista

Abstrak: Kawista merupakan salah satu buah yang tergolong jeruk, bentuknya bulat dengan kulit yang tebal dan keras serta aroma yang khas. Tujuan dari penelitian ini adalah untuk mengetahui kebutuhan konsumen terhadap minuman non kopi dan memproduksi The Blankon. Metode yang digunakan adalah pengembangan pelanggan yang difokuskan pada penemuan pelanggan dengan menggunakan model kanvas. Penelitian dilakukan di kedai kopi di Kota Bogor dari bulan Februari hingga Maret 2020. Hasil penelitian menunjukkan bahwa The Blankon menjawab keinginan pelanggan. Kadar manisnya tergolong cukup (tidak terlalu manis) dan tidak meninggalkan jejak rasa manis di mulut. The Blankon memiliki aroma yang khas, dan menyegarkan sebagai minuman. Berdasarkan hasil penelitian, sekitar 92\% responden berpotensi untuk memilih minuman The Blankon.

Kata kunci: membangun produk, business model canvas, customer discovery, kawista

${ }^{1}$ Corresponding author:

Email: khinsanauran@gmail.com 


\section{INTRODUCTION}

There are many types of drinks in society both traditional drinks and modern drinks. The modernization of types of drinks has developed along with the existence of cafes that are increasingly expanding in big cities and regions. Based on information published by the New York Times (2012), "In many ways, the convenience store's evolution was given in a country like Indonesia, where the penchant for hanging out runs so deep that there is a word for sitting, talking, and generally doing nothing which usually described as "nongkrong". The visitors do not come to functional needs, but to various personal motives and interests which are part of the process of consuming cafe space (Fauzi et al. 2017). According to Salendra (2014), currently, a lot of teenagers update their status or photos when they hang out in cafes or coffee shops on social media to get recognized as their self-actualization.

Bogor City is the one of the urban areas that has pretty fast development of cafes with an average growth from 2011 to 2014 by $111.63 \%$ (Hartono, 2018). Figure 1 presents development of coffee shops in Bogor City from 2011 to 2014.

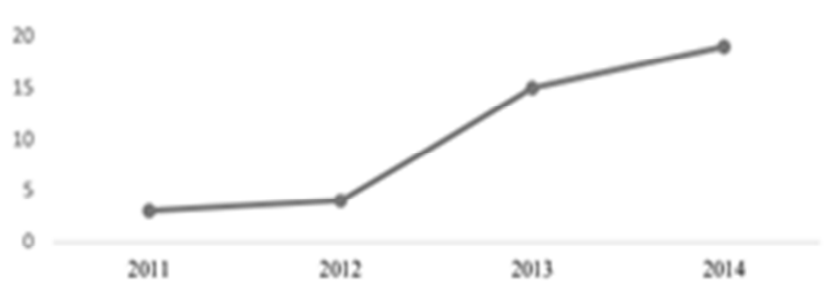

Figure 1. Development of coffee shops in Bogor City 2011-2014 (Integrated Licensing and Investment Service Agency (BPPTPM) Bogor City, 2015)

In general, cafes or coffee shops open until midnight to offer coffee and snacks as mainstay menu. The varieties of coffee shops are very diverse from standard to exclusive. The establishment of coffee shops was inspired by trend of drinking latte and cappuccino as a lifestyle among young people (Herlyana, 2012). Based on data from the National Coffee Association, daily coffee consumption increased in the last eight years. It shows that among 18 to 24 years old consumers rose from $34 \%$ to $48 \%$ and people who aged 25 to 39 years old increased from $51 \%$ to $60 \%$. This shows that the majority of coffee shop visitors or consumers are teenagers and adults (Nurdianah, 2019). Various visitors have inspired to change coffee shop into a drinking place both coffee and non-coffee products. Consumers can choose different types of products to meet their needs, thus making soft drink brands compete not only in one type of drink, but also with other brands from other types of soft drinks (Alamsyah et al. 2010). The research showed that $35 \%$ of soft drinks in Indonesia are consumed for lifestyle activities such as hanging out and celebrations to increase enjoyment (Alamsyah et al. 2010).

Kawista (Limonia acidissima) is a fruit that belongs to the citrus family or Rutaceae. Kawista fruit has round shape with thick and hard skin and has a distinctive aroma (Apriyantono and Kumara, 2004). According to Nugroho (2012), kawista processed only into lemonade, syrup, "madumongso", "jam", and "dodol" in Rembang Regency, Central Java. These products position themselves as typical Rembang souvenirs, and kawista syrup is a mainstay product. Kawista syrup or Cola van Java began to be mass-produced by the people of Rembang since decades ago (Nugroho, 2012). According to Nurdiana (2016), kawista is less well known because it is rarely consumed so it has almost disappeared in the market. Kawista trees in Rembang are quite a lot, but the population decreased due to it takes 15 years to bear fruit (Nugroho, 2012). This situation caused by the low economic value of kawista so that it cannot compete withother fruits. Kawista has a good prospect to be developed because of the various benefits of kawista. Kawista's unique aroma can make millennial generation who generally have a high curiosity character (Putri, 2018). Millennial generation also likes something out of the box, likes challenges and awards, and dares to argue directly or through on social media. Written communication is more comfortable and appropriate by millennial generation with less formal language, more friendly way of communication, and a more familiar tone (Parent Binus, 2018). The characteristics of millennial generation are directly appropriate to make millennials as customers.

Based on this background, The Blankon product design will be carried out to fulfill customer needs for noncoffee beverages. The Blankon is a food and beverage product by utilizing kawista fruit processed, kawista syrup, which is served ready-to-drink in bottles and can be consumed directly at the coffee shop. The unique aroma of Kawista as local drink from the Rembang Regency, has potential to be appointed as a new product that is packaged more modern according to the characteristics of coffee shop visitors in Bogor City. 
The purpose of this research is to identify customer needs for non-coffee as their beverage option to consume while hanging out and create The Blankon product.

\section{METHODS}

The method used was customer development by Blank and Dorf (2012) that focused on customer discovery (preparation of business canvas models, problem testing, solution testing, and verification of canvas business models) used a business model canvas by Osterwalder and Pigneur (2010). According to Blank and Dorf (2012), customer development is a model designed to solve nine problems in product development. Customer discovery is the first stage of customer development which translates the company's vision from a founder into hypotheses about each component of the business model and creates a set of experiments to test each of these hypotheses. Customer discovery aims to test The Blankon's hypothesis to suit customer needs. The study conducted in a coffee shop in Bogor City from February to March 2020. The sample was taken from middle to upper class of millennial generation in Bogor City (55\% from the population of Bogor City) (BPS, 2017). The sampling technique used non-probability sampling with purposive sampling that has certain targets (Indriantoro 2018). Respondent were screened by using Slovin formula to obtain a small sample, but it can represent the entire population. Slovin formula used $1 \%$ of margin error because the population more than 500 people (Muchlis, 2015). Slovin formula is as follow:

$$
\mathrm{n}=\frac{N}{1+N(e)^{2}}
$$

Potential respondents screening were 100 people, then 25 people were selected as respondents for problem testing and solution testing because 25 interviews may sufficient for small projects (Charmaz, 2006). The 25 respondents were taken from those who consumed noncoffee drink in the coffee shopmore than 4 times per month,responded to the new menu in the coffee shop, and asked for information of new product and ordered them at the coffee shop. The potential respondents were asked to fulfill questionnaire, while the respondents were asked to in-depth interviews.

\section{RESULTS}

\section{Market Size}

Total Addressable Market (TAM) is the whole market potential from the millennial generation in Bogor City (594,554 people) (BPS, 2017). While, Served Available Market (SAM) is some part of the whole market that tends to use the product who they are the middle class and upper class of millennial generation in Bogor City (552,282 people). Target Market (TM) is assumed to be $1 \%$ of SAM (5,522 people). Figure 2 presents market size of The Blankon.

\section{Hypothesis of Business Model Canvas (BMC 0)}

Hypothesis of customer segments is coffee shop's visitors which categorized in middle to upper class of millennial generation group in Bogor City who need non-coffee products with unique taste. Hypotheses of value propositions are the unique tastes of kawista, and the concept of the bottle packaging seems like alcoholic drink packaging. Hypotheses of channels are direct (social media) and indirect (direct promotion in coffee shop). Hypotheses of customer relationships are giving souvenirs as a bonus for purchasing in bulk and accept criticism and suggestions through the available platforms. Hypothesis of revenue streams is obtained from selling the product.

Three categories of hypothesis of key resources are human resources (marketing, operational, quality control, and finance), financial resources, and physic resources (tools and materials for production activities). Hypothesis of key activities include production category because these activities include procurement of raw materials, producing the product, quality control, marketing, and distribution. Hypotheses of key partners are raw material providers, packaging providers, and product delivery distributors. Hypotheses of cost structures are fix costs (cost of purchasing production equipment, maintenance cost of production equipment, internet costs, electricity cost, and advertising costs) and variable costs (cost of purchasing raw materials, cost of packaging, cost of shipping raw materials, cost of shipping packaging, and shipping cost of products to the coffee shops). Figure 3 presents hypothesis of business model canvas. 


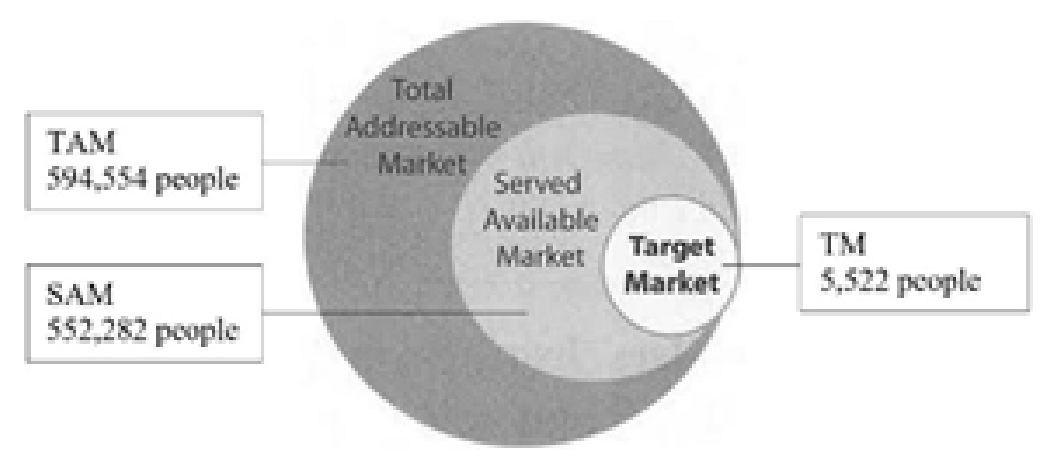

Figure 2. Market size of The Blankon

\begin{tabular}{|c|c|c|c|c|c|}
\hline \multirow[t]{2}{*}{$\begin{array}{l}\text { Key Partners } \\
\text { - Raw material } \\
\text { providers } \\
\text { - Packaging } \\
\text { providers } \\
\text { - Product delivery } \\
\text { distributors }\end{array}$} & $\begin{array}{l}\quad \text { Key Activities } \\
\text { - Procurement of raw } \\
\text { materials } \\
\text { - Producing the product } \\
\text { - Quality control } \\
\text { - Marketing } \\
\text { - Distribution }\end{array}$ & \multirow{2}{*}{\multicolumn{2}{|c|}{$\begin{array}{l}\text { Value Propositions } \\
\text { - Convenience/usability: } \\
\text { The unique taste of } \\
\text { kawista } \\
\text { - Design: The concept } \\
\text { of the bottle packaging } \\
\text { that seems like } \\
\text { alcoholic drink } \\
\text { packaging }\end{array}$}} & $\begin{array}{l}\text { Customer Relationships } \\
\text { - Giving souvenirs as a } \\
\text { bonus for purchasing } \\
\text { in bulk } \\
\text { - Automatic service: } \\
\text { Accept criticism and } \\
\text { suggestions through } \\
\text { the available platforms }\end{array}$ & \multirow[t]{2}{*}{$\begin{array}{l}\text { Customer Segments } \\
\text { - Coffee shop's visitors } \\
\text { which categorized } \\
\text { in middle to upper } \\
\text { class of millennial } \\
\text { generation group in } \\
\text { Bogor City who need } \\
\text { non-coffee products } \\
\text { with unique taste }\end{array}$} \\
\hline & \begin{tabular}{l}
\multicolumn{1}{c}{ Key Resources } \\
- Human resources: \\
Marketing, operational, \\
quality control, and \\
finance \\
- Financial resources \\
- Physic resources: \\
Tools and materials for \\
production activities
\end{tabular} & & & $\begin{array}{l}\text { Channels } \\
\text { - Direct: Social media } \\
\text { - Indirect: Word of } \\
\text { mouth, and coffee } \\
\text { shop }\end{array}$ & \\
\hline \multicolumn{3}{|c|}{$\begin{array}{l}\text { Cost Structures } \\
\text { - Fix costs: Cost of purchasing production equipment, } \\
\text { maintenance cost of production equipment, internet costs, } \\
\text { electricity cost, and advertising costs } \\
\text { - Variable cost: Cost of purchasing raw materials, cost of } \\
\text { packaging, cost of shipping raw materials, cost of shipping } \\
\text { packaging, and shipping cost of products to the coffee shops }\end{array}$} & $\begin{array}{l}\text { Revenue Str } \\
\text { - Sales of pr }\end{array}$ & $\begin{array}{l}\text { eams } \\
\text { oduct of The Blankon }\end{array}$ & \\
\hline
\end{tabular}

Figure 3. Hypothesis of business model canvas (BMC 0)

\section{Problem Testing}

The potential customers have solutions to overcome their problem that are: switching to another product and not consuming the product (for bored problem); switching to another product (for too-sweet problem); switching to another product and not repurchasing (for the expected taste is not a suitable problem); switching to another product and making your drink (for the original taste of desired product does not appear problem); switching to another product, switching the type of drink according to the food, and asking the barista for drink suggestions (for taste does not match problem); switching to another product and istiqomah (for inconsistency taste problem); and switching to another product (for the volume of the drink is not much). Figure 4 presents the potential customers' problems towards the drink.

\section{Business Model Canvas Updated}

There are some updates for customer segments, value propositions, and customer relationships. The age range of the respondents for customer segments was adjusted. Coffee shop visitors with the age range from 20 to 46 years old which were categorized in middle to upper class of society in Bogor City who need noncoffee products with unique taste. The updated value propositions are (i) the unique aroma of kawista, (ii) sweetness is classified as adequate (not-too-sweet) 
and does not leave the sweetness in the mouth, (iii) the product has a distinctive aroma, fresh raw material and refreshing as drinks. The update for customer relationships is accepting criticism and suggestions through the available social media. Figure 5 presents business model canvas updated. Yellow color indicate the updated.

\section{Prototyping}

The majority of the respondents chose clear glass bottles with long-necked $330 \mathrm{ml}$ bottle because it was considered as an eye-catching bottle. The transparent glass would make the drink's dark brown color become more visible. In addition, the it shape will make it easier to grip. $330 \mathrm{ml}$ sized bottle was chosen by the respondents as the ideal volume for the drink. Figure 6 presents the prototype of product of The Blankon and Figure 7 presents the souvenirs of The Blankon.

\section{Solution Testing}

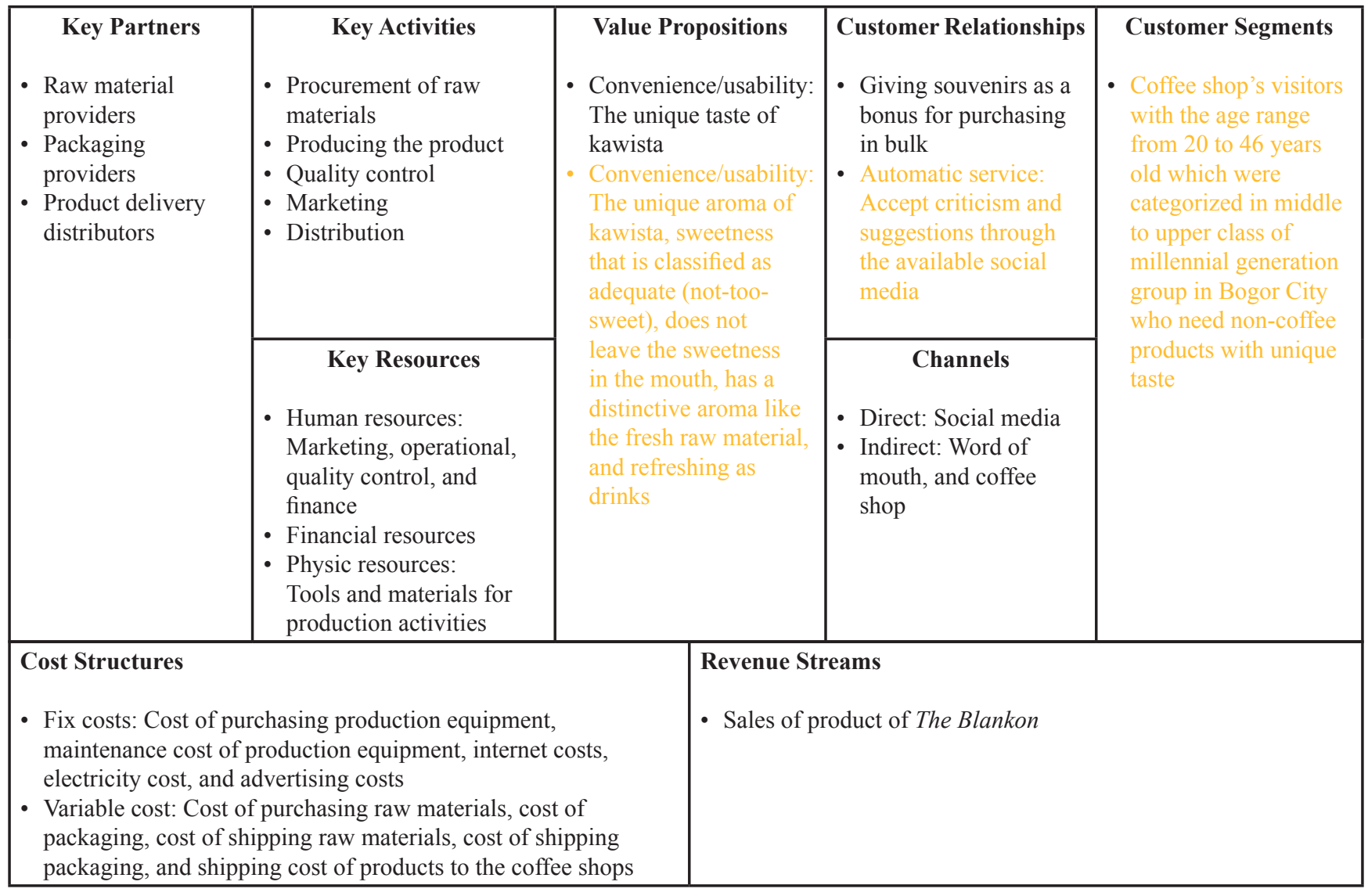

Figure 5. Business model canvas updated 

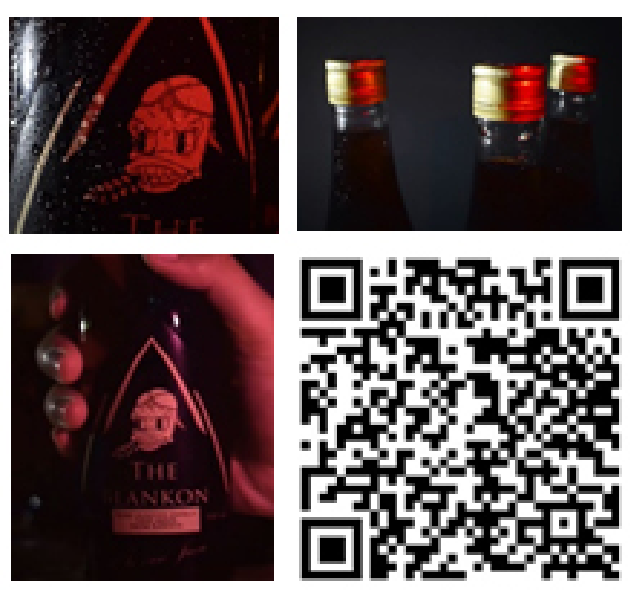

Figure 6. Prototype of product of The Blankon

About $92 \%$ of the respondents agreed that The Blankon have the criteria for the required refreshing drink with adequate sweet taste, the aftertaste does not leave sweetness in the mouth, and original characteristics of the fruit which is represented by the aroma of the drink. The respondents also agreed that The Blankon suits their taste preferences, while $88 \%$ of the respondents answered that The Blankon has attractive packaging design. Social media particularly Instagram often being used, therefore $76 \%$ of the respondents preferred to utilize it as online promotional channel. However, some of the respondents by $24 \%$ preferred offline promotional channel as they rarely pay attention to promotions in social media. The Blankon should be sold in coffee and vape shops as both of the places often visited as gathering place based on the $88 \%$ of the respondents. The average price that the respondent wants to pay for a bottle of The Blankon is Rp 23,000. In addition, there are $92 \%$ of the respondents interested in buying the product of The Blankon and wanted to buy it once a week. The respondents suggested to supply the product to vape shop and restaurants and make a good relationship with barista and coffee shops employee as partner in marketing the product to the customers so they will be interested in making purchases.

\section{Business Model Canvas Updated (BMC 1)}

The update about channels and cost structures. Updated for channels are direct (social media) and indirect (direct marketing, coffee shop, vape shop, and restaurant). Updated for cost structures are fix costs
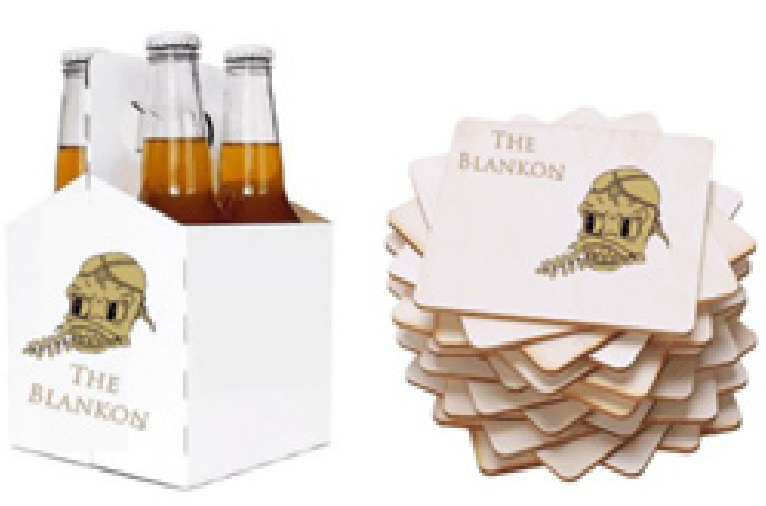

Figure 7. Souvenirs of The Blankon

(cost of purchasing production equipment, internet costs, electricity cost, advertising costs, depreciation cost of production equipment, building rental cost, etc.) and variable cost (cost of packaging, cost of shipping packaging, cost of purchasing kawista syrup, employee cost, cost of purchasing souvenirs, kawista syrup delivery cost, cost of shipping the product to the coffee shop, vape shop, and restaurant). Figure 8 presents business model canvas updated (BMC 1). Yellow and blue colors indicate the updated.

\section{Verification of BMC}

According to Blank and Dorf (2012), there are three things to consider in verifying the business model canvas: compatibility with the market, customer segments and how to reach customers, and how the company makes money:

Compatibility with the market

Based on BMC 1 and market size, The Blankon is under the market. The respondents' problems about the drinks are as follows: bored, too sweet, the expected taste is not suitable, the original taste of desired product does not appear, taste does not match, inconsistent taste, volume of the drink is not much. Based on solution testing, the features on The Blankon provided to solve the problems, because it has a distinctive aroma like fresh raw materials, and refreshing as drinks. The product is served in $330 \mathrm{ml}$ ready-to-drink bottles. 


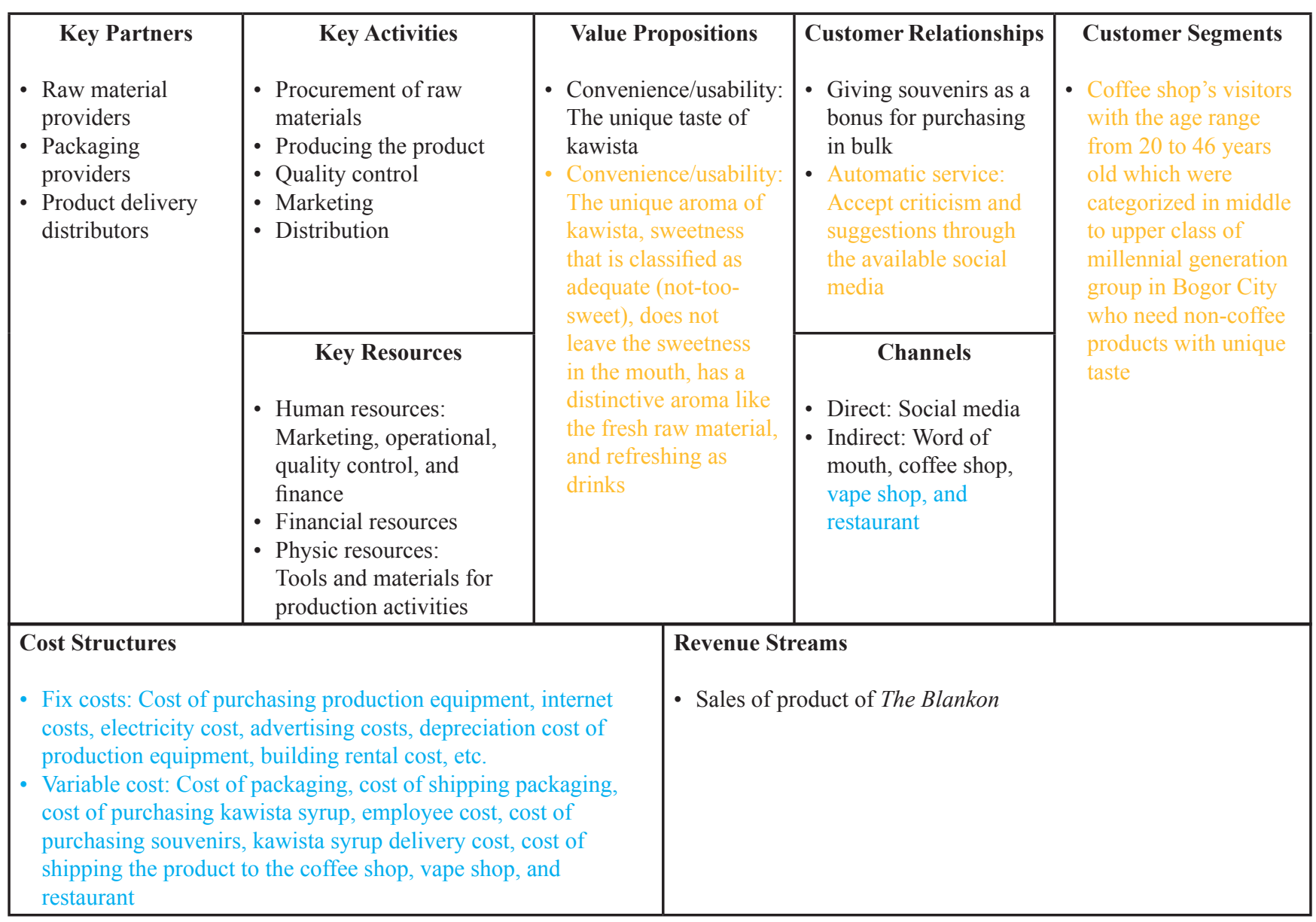

Figure 8. Business model canvas updated (BMC 1)

Customer segments and how to reach customers

Customer segments of The Blankon are coffee shop visitors with the age range of 20 to 46 years old categorized in middle to upper class society in Bogor City who need non-coffee products with a unique aroma. The customer segments are reached by offline sales (coffee shops, vape shops, and restaurants) and online sales by online motorcycle taxi (according to the culture and behavior of urban customers who want to be more instant).

How the company makes money

The main income comes from sales of The Blankon's product. The first target market is 5,522 people. The result of solution testing is $92 \%$ of respondents who interested to buy the product. If it is assumed that the new target market is $92 \%$ of 5,522 , the new target market is 5,080 people with purchasing 1 bottle per week. As a result, The Blankon produce of 20,320 bottles per month. The price of The Blankon is Rp18,000 per bottle with a markup $50 \%$ of the cost production (as the profit can be already taken by $50 \%$ of the sales), so the income is Rp125, 978, 387 per month.

\section{Managerial Implications}

Based on the research that has been done, this research is developed and developed from various theories, the results of previous research, and direct observation to prospective customers. So that the research results have implications for the theory that is the basis and in accordance with what consumers want. The results showed that prospective customers tended to be bored and unsatisfied with the usual drinks they consumed because the levels of the drinks were too sweet and left a sweet trail in the mouth, and did not have the appropriate aroma of the raw material. Based on this, it is necessary to make new products so that customers do not get bored easily and can make repeat purchases. The features of The Blankon product can answer these problems which make this product have the opportunity to enter the city of Bogor as a target market. This is because there are not many business players involved in ready-to-drink beverage products with non-coffee drinks that can be enjoyed directly at coffee shops, vape shops and restaurants in Bogor City. Based on the calculation of the cost of production of $\mathrm{Rp} 11,710$ per bottle with a production target of 20,320 bottles per month, the selling price obtained through coffee 
shops, vape shops and restaurants are Rp. 18,000 per bottle and customers can enjoy The Blankon products for Rp23,000. A large mark up of 50\% of the cost of production can get an income of Rp125,978,387 per month, the amount of revenue with the profit to be earned can be taken into consideration for running this business. In addition, the results of this study indicate that The Blankon's canvas business model is feasible and accepted by potential customers.

\section{CONCLUSIONS AND RECOMMENDATIONS}

\section{Conclusions}

Customer needs for non-coffee as chosen beverage to consume with sweet level are classified as adequate (not too sweet) and not leaving traces in the mouth, a distinctive aroma, and refresh. Hence, The Blankon can fulfil the customers' needs in choosing non-coffee product. The prototype of The Blankon answered $92 \%$ of customers' problems and $92 \%$ of customers is potential to consume products of The Blankon. The production cost is Rp11,710 per bottle with the production target of 20,320 bottle per month. The selling price to coffee shops, vape shops, and restaurants is Rp18,000 per bottle, and customers can enjoy The Blankon with Rp23,000. Therefore, the canvas model business of the product is feasible and accepted by the potential customers.

\section{Recommendations}

The recommedation that can be given are as follow: research shelf-life; conducting content research on product of The Blankon; organoleptic testing; making cooperative agreements with raw materials providers, packing providers, product delivery providers, packaging providers, product delivery distributors; continuous innovation in design product; food product distribution permit; and build other products variants of The Blankon.

\section{REFERENCES}

Alamsyah Z, Sumarwan U, Hartoyo, Yusuf EZ. 2010. Analisis faktor-faktor yang mempengaruhi pilihan jenis minuman pada situasi konsumsi hang-out dan celebration. Jurnal manajemen dan organisasi 1(1): 40-55.
Apriyantono A, Kumara B. 2004. Identifikasi character impact odorants buah kawista (feronia limonia). Jurnal teknologi industri pangan 15(1): 35-45.

[BPS] Badan Pusat Stastistik Kota Bogor. 2017. Bogor dalam angka 2017. https://bogorkota.bps. go.id/statictable/2018/05/14/117/banyaknyapenduduk-menurut-kelompok-umur-dan-jeniskelamin-2017.html [2019 Oct 16].

Blank S, Dorf B. 2012. The startup owner's manual. Jakarta: Elex Media Komputindo.

Charmaz K. 2006. Constructic grounded theory: a practical guide through qualitative analysis. London: Sage Publications Ltd.

Fauzi A, Punia IN, Kamajaya G. 2019. Budaya nongkrong anak muda di kafe (tinjauan gaya hidup anak muda di kota denpasar). Jurnal mahasiswa fakultas ilmu sosial dan ilmu politik universitas udayana. https://simdos. unud.ac.id/uploads/file_penelitian_dir/ aea2d2866dfc667c8d9468881e25b240.pdf [2019 Sept 7].

Hartono D. 2018. Analisis preferensi konsumen di kafe ruang kopi bogor [skripsi]. Bogor: Institut Pertanian Bogor.

Herlyana E. 2014. Fenomena coffee shop sebagai gejala gaya hidup baru kaum muda. Jurnal bahasa, peradaban, dan informasi islam uin sunan kalijaga yogyakarta. http://ejournal.uinsuka.ac.id/adab/thaqafiyyat/article/view/43 [2019 Sept 7].

Indriantoro N, Supomo B. 2018. Metodologi penelitian bisnis untuk akuntansi dan manajemen. Yogyakarta: Andi Offset.

Muchlis I. 2015. Pengaruh stres kerja terhadap kinerja karyawan di pt batik danar hadi surakarta [tesis]. Surakarta: Universitas Muhammadiyah Surakarta.

Nugroho IA, Dorly, Hartana A. 2012. Keragaman kawista (limonia acidissima 1.) di Kabupaten Rembang. Jurnal Mahasiswa departemen biologi, fmipa ipb. Bogor: Fakultas MIPA Institut Pertanian Bogor.

NurdianaZ.2016. Variasi morfologidan pengelompokan kawista (limonia acidissima 1.) di jawa dan kepulauan sunda kecil [tesis]. Bogor: Institut Pertanian Bogor.

Osterwalder A, Pigneur Y. 2015. Business model generation. Jakarta: Elex Media Komputindo.

Parent B. 2018. Generasi x y z. http://parent.binus. ac.id/wp-content/uploads/2018/11/Generasi-XY-Z.pdf [2019 Sept 18]. 
Putri AAKS. 2018. Analisis pengaruh sikap generasi millennial terhadap minat beli online pada situs jejaring sosial [tesis]. Yogyakart: Universitas Islam Indonesia.

Salendra. 2014. Coffee shop as a media for selfactualization today's youth. Jurnal The
Messenger 6(4): 49-52.

Sari IPTP. 2014. Tingkat pengetahuan tentang pentingnya mengkonsumsi air mineral pada siswa kelas iv di sd negeri keputrana yogyakarta. Jurnal Pendidikan Jasmani Indonesia 10(2): $55-61$. 